\title{
ADMIRALTY WILL NOT TRY EQUITABLE TITLES TO VESSELS
}

\author{
By James D. Dewell, $J r$.
}

Many questions arise in practice where it is extremely difficult to advise a client whether the admiralty has jurisdiction of his case; this is particularly true of lawyers who seldom have occasion to look into this most interesting branch of the law.

But there is one class of cases, which clients are continually requesting to have brought in the Admiralty Court and about which there is not the slightest difficulty; namely, cases where an equitable title to a vessel only is in dispute. For the law is, and always has been, that the admiralty has no jurisdiction where equitable titles only are presented. Such questions have no more to do with maritime affairs, except the accidental circumstance that the property may sail the sea, than a dispute over the ownership of a horse. Consequently where the facts present a dispute over a mortgage to secure the purchase price of a vessel; to compel the performance of a mere trust; a question of fraud and mistake over a mortgage; a question of title under a sheriff's sale on execution, where the legal title does not stand in the name of the person against whom the judgment is obtained, etc., the admiralty courts have no jurisdiction and have repeatedly said so. But the Court may decline in its discretion, to enforce a legal title against a meritorious equitable title accompanied by possession. ${ }^{1}$

A very interesting discussion of this question arose over the ownership of a bark. The person filing the libel claimed title to $19 / 32$ of the bark under a sheriff's sale on an execution issued out of a state court on a judgment obtained against one who was alleged to have bought these $19 / 32$ of the bark and caused the title to have been taken in the name of the master, so as to avoid his creditors. The master, who was in possession of the bark and who had a paper title in himself to $26 / 3^{2}$ of the bark including these $19 / 32$, appeared and contested the libel for possession filed by the holder of the $19 / 3^{2}$ under the certificate and bill of sale executed to him by the sheriff.

The argument in behalf of the libellant proceeded upon the theory that the title obtained from the sheriff was a legal title.. But this reasoning of course assumes that the legal title had been

'The G. Rensans, 23 Fed. Rep. 403-404. 
in the person against whom the execution issued; which was not the fact. This obviously left the sole question presented to the court, the equitable ownership of the bark which should have been adjudicated in the proper form before coming into admiralty.

In the same position are libels filed based upon a mortgage, or suits in which the validity of a mortgage is called in question. Such actions are not founded upon maritime contracts and are not subject to admiralty jurisdiction.

In a recent case, the mortgagee of a yacht had taken possession under his mortgage. A libel was filed by mortgagers for possession alleging, among other things, that the mortgagee's title was false and that the mortgage was made upon false representations, etc. The mortgagee filed exceptions to the effect that the court was without jurisdiction. The Court in sustaining the exceptions and dismissing the libel said: "So far, however, as appears from the libel, the question involves a mortgage of the vessel and the Court in order to determine the action would be required to adjudicate upon the validity of the mortgage and try the question of fraud and mistake. Gillespie (mortgagee) is apparently rightfully in possession and until these questions are determined adversely to him, should continue in possession. It is well settled that admiralty will not entertain jurisdiction of a matter of this kind." "

It may be said that the admiralty court is also a court of equity, which is no doubt true, but it cannot try questions involving merely the equitable title to a vessel. In fact, the remedies in admiralty on the subject under discussion, resemble those of the common law more than those in equity; as the admiralty court, like a common law court, will consider the legal title only and will restore a vessel to the one having the legal title without regard to collateral equities. ${ }^{3}$

JAMes D. Deweld, Jr.

2 The Eclipse, 135 U. S., 599; Andrews v. Essex, 3 Mason, 6; Hughes on Admiralty, pgs. 18, 19, and sec. 189, p. 354; The S. C. Ives, Fed. Cas. No. 7,958; The Willian D. Rice, Fed. Cas. No. 17,691 (3 Ware, 134); The Ella I. Slaymaker, 28 Fed Rep., 767; The Amelia, 23 Fed Rep., 407; The Venture, B1 Fed. Rep., 928; The Clifton, 143 Fed. Rep. C. C. A., 460; The Robert B. Kirkland, 92 Fed. Rep., 407; The John Jay, Fed. Cas. No. 1,597; The G. Rensans, 23 Fed. Rep., 403 ;The Helys, 173 Fed. Rep., 928.

${ }^{3}$ Cole v. Brandt, Fed. Cas. No. 2,978. 